\title{
Resim, Müzik ve Beden Eğitimi Öğretmen Adaylarinin Öğrenme Stilleri"
}

\section{Learning Styles of Art, Music and Physical Education Pre-Service Teachers}

\begin{abstract}
$\mathrm{DOI}=\underline{10.17556 / \mathrm{jef}_{.} 38844}$
Hüseyin Hüsnü BAHAR ${ }^{* *}$, Recep POLAT ${ }^{* * *}$, Mehmet ÖZBAŞ $^{* * * *}$

Extended Summary

Purpose

The purpose of this research was to investigate learning styles of students registered in teacher training program accepting students through the special talent exam. Within this scope, dominant learning styles of pre-service Visual Arts, Music and Physical Education and Sports teachers were analyzed. Whether the distribution differed according to the dominant learning styles of pre-service teachers or not investigated, and whether there was a significant difference between the registered teacher training program and learning style or not was searched. Moreover, it was also aimed to determine whether score averages related to learning style components differed or not according to the registered teacher training program.
\end{abstract}

\section{Method}

The study group included 350 students studying at Art teaching, Music Teaching and Physical Education and Sports Teaching departments of Erzincan University, Faculty of Education in 2015-2016 academic year. In the group, 103 of the participants were the students registered in Arts Teaching, 127 were the students in Music Teaching and 127 were the students registered in Physical Education and Sports teaching programs. The study group included 192 male and 158 female students.

Kolb's Learning Style Inventory was used as the data collection tool. Learning Style Inventory (LSI) developed by Kolb was adapted into Turkish by Aşkar and Akkoyunlu. The inventory included 12 expressions, and there were 4 propositions in each group. The answerers were asked to rank these four

\footnotetext{
* Bu çalışmanın bir bölümü Kazakistan'da yapılan "By Unesco Roads: World, Art Education,Youth" başlıklı uluslararası sempozyumda bildiri olarak sunulmuş, özet veya tam metin olarak bildiri kitabı dahil hiçbir yerde yayınlanmamıștır.

** Doç. Dr., Erzincan Üniversitesi Eğitim Fakültesi, hhbahar@erzincan.edu.tr

*** Prof. Dr., Erzincan Üniversitesi Eğitim Fakültesi, rpolat@erzincan.edu.tr

**** Doç. Dr., Erzincan Üniversitesi Eğitim Fakültesi, mozbas@erzincan.edu.tr
} 
propositions in ach group scoring as 1, 2, 3, and 4 from the most appropriate for the self to the least. If AC-CE (Abstract Conceptualization-Concrete Experience) score of the answerer was below 4 and AE-RO (Active Experimentation-Reflective Observation) score was above 5, then the learning style was accommodating; if AC$\mathrm{CE}$ score of the answerer was below 4 and AE-RO score was below 5, then the learning style was defined as diverging. On the other hand, if AC-CE score of the answerer was above 4 and AE-RO score was above 5, then the learning style was converging, and if below 5, then the learning style was defined as assimilating.

\section{Results}

Distributions of the participants according to their learning styles were noticed to differ significantly. Whereas $62.9 \%$ of the students were determined to have diverging learning style, the rate for the students with accommodating, converging and assimilating learning styles were noticed to be less than expected. No significant relationship was specified between the learning style and registered program. Whereas no significant difference was determined between Concrete Experience (CE) and Reflective Observation 8RO) in learning style components according to the registered program, significant difference was specified in other sub-components. In Abstract Conceptualization (AC) dimension, a significant difference was found between Physical Education and Music and Arts groups; and a significant difference was also specified in Active Experimentation (AE), AC-CE and AE-RO components between Music and physical Education teaching groups.

\section{Discussion}

The distribution of the participants according to their learning styles was not balanced. Diverging learning style was clearly noticed to be the dominant learning style of all three groups. In the relevant literature, there were studies with similar and different results. The results obtained from the current study were different from results of the similar researches carried out upon pre-service teachers in other branches. This difference was considered to be arisen from the difference in intended population of this study and the intended population of the similar researches. Teaching programs of the study group were full of courses and activities prioritizing the development of kinetic skills more. For that reason, it should be considered as natural to have difference between the learning style of the study group and the learning styles of the students registered in teacher training programs with intensive cognitive content. A significant part of the students in the groups were understood to prefer learning through monitoring and feeling more. Considering that program contents intensively included kinetic skills in all three groups, this obtained result was possible to be mentioned as not totally surprising. When we included the assimilators learning through monitoring and thinking, observation-based learning could be mentioned as an important need in these groups. On the other hand, the rates for learners as experiencing-thinking and experiencing-feeling were observed to be lower in the groups. Nonetheless, the presence of practicing environments was remarkable for such learners.

\section{Conclusion}

Whereas a significant part of the participants had diverging learning style, the rate for the students with accommodating, assimilating and converging learning 
styles was a lot lower. In all three groups, the distribution rate for the students according to their learning styles was similar. The registered program and learning style was not correlated. However, when the relevant literature was reviewed, the learning style dominant in this study group was understood to be different from the other teaching branches. For that reason, carrying out a similar study comparing different teaching groups could reveal different results.

There was no significant difference in $\mathrm{CE}$ and $\mathrm{RO}$ components between score averages related to the learning style components according to the registered program. In $\mathrm{CE}$ and $\mathrm{RO}$ dimensions, the scores related to all three groups were similar. However, Physical Education group was noticed to be differed rather than the Art and Music groups in AC scores. On the other hand, Physical Education group differed from Music group in $\mathrm{AE}, \mathrm{AC}-\mathrm{CE}$ and $\mathrm{AE}-\mathrm{RO}$ dimensions. 